\title{
Research Trends of Ecotoxicity of Nanoparticles in Soil Environment
}

\author{
Woo-Mi Lee, Shin Woong Kim, Jin II Kwak, Sun-Hwa Nam, Yu-Jin Shin and Youn-Joo An \\ Department of Environmental Science, Konkuk University, Seoul 143-701, Korea
}

(Received October 27, 2010; Revised November 6, 2010; Accepted November 14, 2010)

\begin{abstract}
We are consistently being exposed to nanomaterials in direct and/or indirect route as they are used in almost all the sectors in our life. Nations across the worlds are now trying to put global regulation policy on nanomaterials. Sometimes, they are reported to be more toxic than the corresponding ion and micromaterials. Therefore, safety research of nanoparticles has huge implications on a national economics. In this study, we evaluated and analyzed the research trend of ecotoxicity of nanoparticles in soil environment. Test species include terrestrial plants, earthworms, and soil nematode. Soil enzyme activities were also discussed. We found that the results of nanotoxicity studies were affected by many factors such as physicochemical properties, size, dispersion method and test medium of nanoparticle, which should be considered when conducting toxicity researches. In particular, more researches on the effect of physicochemical properties and fate of nanoparticles on toxicity effect should be conducted consistently.
\end{abstract}

Key words: Nanoparticle/Nanomaterials, Ecotoxicity, Earthworm, Plant, Soil nematode

\section{INTRODUCTION}

Nanotechnology has been applied to various fields such as medical science, industry, IT, energy, food, and environment. According to Global Environment Outlook (GEO) annual report by UN, nanotech-products will account for more than $14 \%$ of the total products or $\$ 2.6$ trillion by 2014, up from less than $0.1 \%$ in 2004 (UNEP, 2007). Nanomaterials are used in various products including appliances, electronics \& computers, automotive, health \& fitness, food $\&$ beverage, cross cutting, goods for children and home $\&$ garden, among which they are used most frequently in personal care, clothing and cosmetic sunscreen (http://www. nanotechproject.org/inventories/consumer/analysis_draft/). That means people are repetitively exposed to nanoparticles through various routes.

Nanoparticles exhibit greater reactivity as their sizes, less than $100 \mathrm{~nm}$ size, are so small that their surface area is larger. Their transitional zone between atom or molecule and corresponding bulk material is more far from one another, which makes the original characteristics of the substance change (Hoet et al., 2004; Lin and Xing, 2007; Moore, 2006; Nel et al., 2006; Yang and Watts, 2005). It is also reported that such small size of substances can intrude

Correspondence to: Youn-Joo An, Department of Environmental Science, Konkuk University, Seoul 143-701, Korea

E-mail: anyjoo@konkuk.ac.kr into human body more easily and is more toxic than bulk material due to increased reactivity to cells in the body. International society is focusing on the toxicity of nanoparticle, and is hurriedly coming up with regulation on them. European Union gives six months prior report to the Commission before responsible person imports cosmetic product containing nanonmaterial into European nations under its cosmetics law (EC, 2009). According to the REACH regulation, manufacturers and importers are supposed to submit information about physicochemical properties and toxicity of nanomaterials (UBA, 2009). It recently passed an amendment in RoHS Directive (2002/95/EC), which restricts the use of silver nanoparticle and carbon nanotube in electronic goods (KORTRACT, 2010). US EPA recently defined silver nanoparticle as one of pesticides, and made the products go through mandatory approval process after studying their safety information under its Federal Insecticide, Fungicide, and Rodenticide Act (FIFRA).

It is considered that nanotechnology will bring opportunity to improve national competitiveness and profits in several industrial fields. However, toxicity and risk of nanoparticles should be considered in advance. In this study, we investigated the overall trend of studies on nano-ecotoxicity in soil environment. We collected SCI(E) papers regarding nanotoxicity for plants, earthworms, soil nematode and soil enzyme activities, and thoroughly analyzed research trends of nanoecotoxicty to get a better understanding how nanoparticles can be harmful in soil ecosystem. 


\section{NANOTOXICITY IN SOIL ENVIRONMENT}

This study collected the $41 \mathrm{SCI}(\mathrm{E})$ papers on plants, earthworms, nematode, and soil enzyme activities, among which researches on plants accounted for the majority of them. Aquatic toxicity studies usually focused on carbon based nanoparticles such as fullerene (C60), single-wall carbon nanotubes (SWNTs), and multi-wall carbon nanotubes (MWNTs) while soil toxicity studies focused on metal (oxide) based nanoparticles.

Plant toxicity studies. Table 1 lists the studies on nanotoxicity of terrestrial plants. Researches on the effect of nanotoxicity on plants often used aqueous solution, filter paper, and agar media. Nanotoxicity studies on plant have been conducted with various species and nanoparticles since the first report of Yang and Watts (2005). They conducted a research on the effects of $\mathrm{Al}_{2} \mathrm{O}_{3}$ nanoparticles

Table 1. Nanotoxicity studies for terrestrial plants

\begin{tabular}{|c|c|c|c|c|}
\hline Test NP & Test species & Note & Country & Author/Year \\
\hline $\mathrm{Al}_{2} \mathrm{O}_{3}$ & $\begin{array}{l}\text { Zea mays (maize), Cucumis sativus } \\
\text { (cucumber), Glycine max (soybean), } \\
\text { Brassica oleracea (wild cabbage), } \\
\text { Daucus carota (carrot) }\end{array}$ & $\begin{array}{l}\text { Phytotoxicity of Al nanoparticles } \\
\text { loaded with and without } \\
\text { phenanthrene }\end{array}$ & USA & $\begin{array}{l}\text { Yang and Watts, } \\
2005\end{array}$ \\
\hline $\begin{array}{l}\mathrm{MWNT}, \mathrm{Al}, \mathrm{ZnO}, \\
\mathrm{Zn}, \mathrm{Al}_{2} \mathrm{O}_{3}\end{array}$ & $\begin{array}{l}\text { Brassica napus (rape), Raphanus } \\
\text { sativus (radish), Lolium perenne } \\
\text { (ryegrass), Lactuca sativa (lettuce), Zea } \\
\text { mays, Cucumis sativus }\end{array}$ & $\begin{array}{l}\text { Phytotoxicity of five species } \\
\text { nanoparticles }\end{array}$ & China\&USA & Lin and Xing, 2007 \\
\hline $\mathrm{TiO}_{2}$ & Spinacia oleracea (spinach) & $\mathrm{N}_{2}$ fixation in plant by $\mathrm{TiO}_{2}$ & China & Yang et al., 2007 \\
\hline SWNTs & $\begin{array}{l}\text { Brassica oleracea (cabbage), Daucus } \\
\text { carota, Cucumis sativus, Allium cepa } \\
\text { (onion), Lycopersicon esculentum } \\
\text { (tomato), Lactuca sativa }\end{array}$ & $\begin{array}{l}\text { Phytotoxicity of functionalized and } \\
\text { nonfunctionalized SWNT on plant }\end{array}$ & USA & Cañas et al., 2008 \\
\hline $\mathrm{Fe}_{3} \mathrm{O}_{4}$ & $\begin{array}{l}\text { Cucurbita maxima (Pumpkin), } \\
\text { Phaseolus limensis (lima bean) }\end{array}$ & $\begin{array}{l}\text { Uptake, translocation and } \\
\text { accumulation of } \mathrm{Fe}_{2} \mathrm{O}_{3}\end{array}$ & USA & Zhu et al., 2008 \\
\hline Carbon coated-Fe & Cucurbita pepo (pumpkin) & NP transformaton in plant & Spain & $\begin{array}{l}\text { Gonzalez-Melendi } \\
\text { et al., } 2008\end{array}$ \\
\hline $\mathrm{Pd}$ & Hordeum vulgare L. cv. Barke (barely) & Bioaccumlation and growth by $\mathrm{Pb}$ & Germany & Battke et al., 2008 \\
\hline $\mathrm{ZnO}$ & Lolium perenne & Uptake and toxicity of $\mathrm{ZnO}$ & China\&USA & Lin and Xing, 2008 \\
\hline $\mathrm{Cu}$ & $\begin{array}{l}\text { Phaseolus radiatus (mung bean), } \\
\text { Triticum aestivum (wheat) }\end{array}$ & $\begin{array}{l}\text { Phytotoxicity of CuNP using plant } \\
\text { agar test }\end{array}$ & Korea & Lee et al., 2008 \\
\hline $\mathrm{Al}$ & $\begin{array}{l}\text { Phaseolus vulgaris (California red } \\
\text { kidney bean), Lolium perenne }\end{array}$ & Effect of AlNP to plant & USA & Doshi et al., 2008 \\
\hline $\mathrm{Ag}$ & Allium cepa & $\begin{array}{l}\text { Cytotoxic and genotoxic impact of } \\
\text { plant }\end{array}$ & India & Kumari, 2009 \\
\hline $\begin{array}{l}\mathrm{Ag}, \mathrm{MWCNT}, \mathrm{Cu} \\
\mathrm{ZnO}, \mathrm{Si}\end{array}$ & Cucurbita pepo & $\begin{array}{l}\mathrm{NP} \text { and } \mathrm{BP} \text { effect to seed } \\
\text { germination, root elongation, and } \\
\text { biomass }\end{array}$ & USA & $\begin{array}{l}\text { Stampoulis et al., } \\
2009\end{array}$ \\
\hline $\mathrm{Au}, \mathrm{Ag}, \mathrm{Fe}_{3} \mathrm{O}_{4}$ & Lactuca sativa, Cucumis sativus & $\begin{array}{l}\text { Several nanoparticles toxicity effect } \\
\text { to plant and microbial }\end{array}$ & Spain & $\begin{array}{l}\text { Barrena et al., } \\
2009\end{array}$ \\
\hline $\mathrm{Si}, \mathrm{Pd}, \mathrm{Au}, \mathrm{Cu}$ & Lactuca sativa & $\begin{array}{l}4 \text { metal nanoparticles toxicity effect } \\
\text { to seed germination }\end{array}$ & USA & $\begin{array}{l}\text { Shah and } \\
\text { Belozerova, } 2009\end{array}$ \\
\hline SWNT & $\begin{array}{l}\text { Nicotiana tobacum L.cv. Bright Yellow } \\
\text { (BY-2) cells }\end{array}$ & SWNT transports in plant cells & China & Lin et al., 2009 \\
\hline MWNT, $\mathrm{C}_{70}$ & Rice & $\begin{array}{l}\text { Uptake and bioaccumulation of } \\
\text { CNT in plant }\end{array}$ & USA & Liu et al.. 2009 \\
\hline MWNT & Rice cell & Effect of MWNT to rice cell & Japan & Tan et al., 2009 \\
\hline MWCT & Tomato seeds & $\begin{array}{l}\text { Effect of MWNT to tomato seed } \\
\text { germination and growth rate }\end{array}$ & USA & $\begin{array}{l}\text { Khodakovskaya et } \\
\text { al., } 2009\end{array}$ \\
\hline MWNT, $\mathrm{TiO}_{2}, \mathrm{CeO}_{2}$ & Triticum aestivum & $\begin{array}{l}\text { Proposed investigation method of } \\
\text { NP in plants cell }\end{array}$ & UK & Wild et al., 2009 \\
\hline $\begin{array}{l}\mathrm{TiO}_{2} \\
\mathrm{TiO}_{2}\end{array}$ & $\begin{array}{l}\text { Willow tree } \\
\text { Zea mays L. }\end{array}$ & $\begin{array}{l}\text { Acute toxicity test of } \mathrm{TiO}_{2} \\
\text { Effect of } \mathrm{TiO}_{2} \text { on root water } \\
\text { transport }\end{array}$ & $\begin{array}{l}\text { Denmark } \\
\text { Israel }\end{array}$ & $\begin{array}{l}\text { Seeger et al., } 2009 \\
\text { Asli and Neumann, } \\
2009\end{array}$ \\
\hline
\end{tabular}


Table 1. Continued

\begin{tabular}{|c|c|c|c|c|}
\hline Test NP & Test species & Note & Country & Author/Year \\
\hline $\mathrm{TiO}_{2}$ & Arabidopsis thaliana (Arabidopsis) & $\begin{array}{l}\text { Uptake and distribution of } \mathrm{TiO}_{2} \text { in } \\
\text { plant }\end{array}$ & USA & Kurepa et al., 2010 \\
\hline $\begin{array}{l}\mathrm{Al}_{2} \mathrm{O}_{3}, \mathrm{SiO}_{2}, \mathrm{Fe}_{3} \mathrm{O}_{4} \\
\mathrm{ZnO}\end{array}$ & Arabidopsis thaliana & $\begin{array}{l}4 \text { metal NP and bulk materials } \\
\text { toxicity to plant }\end{array}$ & USA & Lee et al., 2010 \\
\hline $\begin{array}{l}\mathrm{La}_{2} \mathrm{O}_{3}, \mathrm{Gd}_{2} \mathrm{O}_{3}, \mathrm{CeO}_{2} \\
\mathrm{Yb}_{2} \mathrm{O}_{3}\end{array}$ & $\begin{array}{l}\text { Brassica napus, Raphanus sativus, } \\
\text { Triticum aestivum, Lactuca sativa, } \\
\text { Brassica oleracea, Lycopersicon } \\
\text { esculentum, Cucumis sativus }\end{array}$ & $\begin{array}{l}\text { Two rare earth oxide nanoparticles } \\
\text { effect to plant }\end{array}$ & China & Ma et al., 2010 \\
\hline $\mathrm{ZnO}, \mathrm{CeO}_{2}$ & Glycine $\max$ & $\begin{array}{l}\text { Random amplified polymorphic } \\
\text { DNA (RAPD) assay }\end{array}$ & Puerto Rico & $\begin{array}{l}\text { Lopez-Morenoetal., } \\
2010\end{array}$ \\
\hline $\mathrm{Pb}$ & Kiwi & $\mathrm{Pb}$ toxicity to kiwifruit pollen & Italy & $\begin{array}{l}\text { Speranza et al., } \\
2010\end{array}$ \\
\hline $\mathrm{Fe}_{3} \mathrm{O}_{4}$ & $\begin{array}{l}\text { Lolium perenne } \mathrm{L} ., \\
\text { Cucurbita mixta }\end{array}$ & $\begin{array}{l}\text { Physiological effect of magnetic NP } \\
\text { on plant }\end{array}$ & USA\&China & Wang et al., 2010 \\
\hline
\end{tabular}

loaded with and without phenanthrene on root elongation of five plants (Zea mays, Cucumis sativus, Glycine max, Brassica oleracea, and Daucus carota). Lin and Xing (2007) performed a research on the effects of MWNTs, $\mathrm{Al}_{2} \mathrm{O}_{3}, \mathrm{Al}$, $\mathrm{Zn}$, and $\mathrm{ZnO}$ nanoparticles on root elongation of plants, and found that $\mathrm{Zn}$ and $\mathrm{ZnO}$ nanoparticles affected plant germination and had the largest effects in root elongation. $\mathrm{Zn}$ and $\mathrm{ZnO}$ nanoparticles were most common used in such researches, and many reported that they induced the decrease in biomass and change in root shape (Lin and Xing, 2008). Lee et al. (2010) found that $\mathrm{ZnO}$ nanoparticle was most toxic than $\mathrm{Al}_{2} \mathrm{O}_{3}, \mathrm{SiO}_{2}$, and $\mathrm{Fe}_{3} \mathrm{O}_{4}$ nanoparticles. Whereas, Stampoulis et al. (2009) reported that they did not see any significant effects of $\mathrm{ZnO}$ on Cucurbita pepo. Aluminum did not accumulate in Phaseolus vulgaris when P. vulgaris and Lolium perenne were exposed to Aluminum, but did accumulate in L. perenne 2.5 times more than in control (Doshi et al., 2008). There is a report that $\mathrm{TiO}_{2}$ reduced the use of water in Z. may, and change the path of apoplast (Asli and Neumann, 2009), while not affecting willow tree in such aspects as growth, production and water use efficiency (Seeger et al., 2009). Copper nanoparticle caused that growth inhibition of Phaseolus radiates and Triticum aestivum using plant agar test (Lee et al., 2008). Battke et al. (2008) observed the effect of the particle size of palladium $(\mathrm{Pd})$ nanoparticle on barley, and found out that barely leaves accumulated palladium nanoparticle. In addition, it is reported that $\mathrm{Ag}$ nanoparticle reduced biomass and transpiration of C. pepo, and affected the germination of C. sativus, but did not have any effects on Lactuca sativa (Stampoulis et al., 2009). Zhu et al. (2008) evaluated uptake, translocation, and accumulation of $\mathrm{Fe}_{2} \mathrm{O}_{3}$ nanoparticle in pumpkin and lima bean. These results were varied depending on the types of media (growth liquid medium, sand, and soil) of test. They identified magnetic signal in pumpkin plant while the magnetic signal was not detected in lima bean. In liquid media, magnetic signal was detected in all pumpkin plant tissue. However, magnetic signal was not detected in soil test. Cañas et al. (2008) observed root elongation of functionalized and nonfunctionalized SWNTs on six crop plants species (Brassica oleracea, D. carota, C. sativus, Allium cepa, Lycopersicon esculentum, and L. sativa). They found that SWNTs with nonfunctionalized had more effects on plants than those functionalized, and the effect was clearer to see when the plants were exposed to them for 24 hours rather than 48 hours. In a research about the effect of $\mathrm{C}_{70}$ on rice, $\mathrm{C}_{70}$ was transmitted to the progeny through seeds (Lin et al., 2009). MWNTs increased oxidative stress and reduced the number of living cells in rice cells (Tan et al., 2009). Liu et al. (2009) found that SWNTs penetrate the plant cell and cell membrane. Kumari et al. (2009) performed an experiment cytotoxic and genotoxic of Ag nanoparticle using A. cepa roots cell. The toxicity effect evaluated using mitotic index (MI), distribution of cells in mitotic phase, different type of chromosomal aberrations, disturbed metaphase, sticky chromosome, cell wall disintegration, and breaks of root tip cell. They were found that chromosomal aberration was not observed and MI value was decreased with Ag nanoparticle concentration dependent. Loìpez-Moreno et al. (2010) performed biotransformation and genotoxicity of $\mathrm{ZnO}$ and $\mathrm{CeO}_{2}$ nanoparticles using G. $\max$. They found that biotransformation of nanoparticles in plant and DNA damage and mutations by nanoparticles.

Earthworm toxicity studies. Table 2 lists earthworm nanotoxicity studies. Petersen et al. (2008) exposed C-14 labeled MWNTs and SWNTs to Eisenia foetida in two different natural soils. They assessed uptake and depuration of earthworm exposed to MWNTs and SWNTs. ScottFordsmanda et al. (2008) observed lethal and sub-lethal toxicity to Eisenia veneta while providing carbon nanotubes amended food. They provided food contaminated with double-walled carbon nanotubes (DWNTs) and $\mathrm{C}_{60}$ every 7 day to earthworms, and 28 days later, they 
Table 2. Nanotoxicity studies for earthworms

\begin{tabular}{|c|c|c|c|c|}
\hline Test NP & Test species & Note & Country & Author/ Year \\
\hline MWNT, SWNT & Eisenia foetida & CNT toxicity and bioaccumlation to earthworm & USA & Petersen et al., 2008 \\
\hline DWNT, $\mathrm{C}_{60}$ & Eisenia veneta & CNT toxicity to earthworm & Danmark & Scott-Fordsmand et al., 2008 \\
\hline $\mathrm{TiO}_{2}, \mathrm{ZnO}$ & Eisenia foetida & $\begin{array}{l}\text { Acute and chronic toxicity test of } \mathrm{ZnO} \text { and } \mathrm{TiO}_{2} \\
\text { nanoparticles }\end{array}$ & USA & Qi, 2009 \\
\hline $\mathrm{Al}_{2} \mathrm{O}_{3}$ & Eisenia foetida & Effect of NP and BP of aluminum in earthworm & USA & Coleman et al., 2010 \\
\hline $\mathrm{TiO}_{2}, \mathrm{ZnO}$ & Eisenia foetida & Toxicity of $\mathrm{TiO}_{2}$ and $\mathrm{ZnO}$ to earthworm & China & Hu et al., 2010 \\
\hline
\end{tabular}

Table 3. Nanotoxicity studies for soil nematode

\begin{tabular}{|c|c|c|c|c|}
\hline Test NP & Test species & Note & Country & Author/Year \\
\hline $\mathrm{Pt}$ & Caenorhabditis elegans & Toxic & Japan & al., 2008 \\
\hline $\mathrm{Ag}$ & Caenorhabditis elegans & Gene expression analysis & Korea & Roh et al., 2009 \\
\hline $\mathrm{CeO}_{2}, \mathrm{TiO}_{2}$ & Caenorhabditis elegans & $\begin{array}{l}\text { Gene expression, growth, mortality of } C \text {. elegans exposed } \\
\text { to } \mathrm{CeO}_{2} \text { and } \mathrm{TiO}_{2}\end{array}$ & Korea & Roh et al., 2009 \\
\hline $\mathrm{ZnO}$ & Caenorhab & Toxicity of $\mathrm{ZnO}$ in C. elegans & USA & l., 2009 \\
\hline $\mathrm{ZnO}, \mathrm{Al}_{2} \mathrm{O}_{3}, \mathrm{TiO}_{2}$ & Caenorhabditis elegans & Toxicity of $\mathrm{ZnO}, \mathrm{Al}_{2} \mathrm{O}_{3}$, and $\mathrm{TiO}_{2} \mathrm{NP}$ and $\mathrm{BP}$ in C. elegans & USA & Wang et al., 2009 \\
\hline
\end{tabular}

observed that the nanoparticles did not affect on their hatchability, growth, and survival, but it caused toxic to earthworm reproduction (cocoon production). In particular, $\mathrm{C}_{60}$, when given as food contaminated with $1000 \mathrm{mg} /$ $\mathrm{kg}$ of $\mathrm{C}_{60}$, reduced the reproduction rate to $78 \%$. Hu et al. (2010) observed toxicity effect exposed $\mathrm{TiO}_{2}$ and $\mathrm{ZnO}$ nanoparticles to earthworms. They found significant DNA damage as result of comet assay to earthworms when doses were greater than $1.0 \mathrm{~g} / \mathrm{kg}$. Bioaccumulation of $\mathrm{Ti}$ and $\mathrm{Zn}$ in earthworm was increased exposure nanoparticle concentration dependent. Qi (2009) performed acute (filter paper and sand test) and chronic (artificial soil and sandmature) toxicity with $\mathrm{TiO}_{2}$ and $\mathrm{ZnO}$ nanoparticles. Toxic effects were observed in filter paper (acute test) and artificial soil test (chronic test) with $\mathrm{ZnO}$ nanoparticles, but no toxicity was observed with $\mathrm{TiO}_{2}$ nanoparticles. Neither of the $\mathrm{ZnO}$ and $\mathrm{TiO}_{2}$ nanoparticles showed toxicity effect in sand (acute test), but chronic toxicity in sand-manure observed toxicity effect. Coleman et al. (2010) performed a chronic toxicity test using $\mathrm{Al}_{2} \mathrm{O}_{3}$ nanoparticle in different particle sizes, and found that no earthworm died when they gave them up to $10000 \mathrm{mg} / \mathrm{kg}$ of $\mathrm{Al}_{2} \mathrm{O}_{3}$ nanoparticle. Bioaccumulation increased when the particle size was smaller. In addition, they reported that earthworms avoid the NP amended soil at the exceeded $5000 \mathrm{mg} / \mathrm{kg}$ of $\mathrm{Al}_{2} \mathrm{O}_{3}$ nanoparticles.

Soil nematode toxicity studies. Table 3 shows the nanotoxicity studies lists of soil nematode. Most of researches have been performed using $C$. elegans, the most well-known soil nematode and evaluated the level of toxicity of nanoparticle in various test method based on the existing standard test methods. Roh et al. (2009) evaluated genotoxicity, survival, growth, and reproduction of $C$. ele- gans for Ag nanoparticles dispersed in K-medium. They found that $\mathrm{Ag}$ nanoparticles reduced reproduction of $C$. elegans supposedly due to oxidative stress. Wang et al. (2009) compared to toxicity of $\mathrm{ZnO}, \mathrm{Al}_{2} \mathrm{O}_{3}$, and $\mathrm{TiO}_{2}$ nanoparticles depending on their particle size (bulk and nano). Nanoparticle and bulk-particle significantly affected the growth and reproduction of $C$. elegans, and particularly, $\mathrm{Al}_{2} \mathrm{O}_{3}$ and $\mathrm{TiO}_{2}$ nanoparticles affected them differently depending on their particle sizes. Ma et al. (2009) compared toxicity between of $\mathrm{ZnO}$ nanoparticle and $\mathrm{ZnCl}_{2}$. They reported that there is no significant effect on lethality, behavior, reproduction, and transegene expression of C. elegans. Roh et al. (2010) investigated toxicity of $\mathrm{CeO}_{2}$ and $\mathrm{TiO}_{2}$ nanoparticles using gene expression, growth, fertility, and survivals as endpoint in $C$. elegans. They were found that fertility and survival were may be related with the cyp35a2 gene. Kim et al. (2008) confirmed the toxicity of platinum nanparticle by observing oxidative stress levels in C. elegans using ROS effect and SOD activity observation.

Soil enzyme activity studies. Table 4 listed soil enzyme activity of nanoparticles studies. Hänsch and Emmerling (2010) were assessment of Ag nanoparticles toxicity using six soil enzymes assay (eucine-aminopeptidase, $\beta$-cellobiohydrolase, acid phosphatase, $\beta$-Glucosidase, chitinase, and xylosidase), and found no significant toxicity in them. Also, Tong et al. (2007) reported no significant effects of $\mathrm{C}_{60}$ on four soil enzymes assay ( $\beta$-Glucosidase, acid phosphatase, dehydrogenase, and Urease).

\section{TREND OF NANOTOXICITY IN SOIL ENVIRONMENT}

Nanotoxicity studies on soil organisms such as plants, 
Table 4. Nanotoxicity studies for soil enzyme activities

\begin{tabular}{lllll}
\hline \hline Test NP & Enzyme & Note & Country & Author/Year \\
\hline $\mathrm{C}_{60}$ & eucine-aminopeptidase, & Impact of $\mathrm{C}_{60}$ on soil microbial & USA & Tong et al., 2007 \\
& $\begin{array}{l}\beta \text {-cellobiohydrolase, acid phosphatase, } \\
\text { B-Glucosidase, chitinase, xylosidase }\end{array}$ & & & \\
& $\begin{array}{l}\text { B-Glucosidase, acid phosphatase, } \\
\text { dehydrogenase, Urease }\end{array}$ & Effect of AgNP to soil microbial activity & Germany & Hnsch and Emmerling, \\
& & & & 2010 \\
\hline
\end{tabular}

earthworms, nematode, and enzyme activity collected here can be sorted out as 29 on plants, 5 on earthworms, 5 on soil nematode, and 2 on soil enzyme activity in terms of subjects (Fig. 1(A)). Plants and earthworm were the representative soil organisms among them. And they can be sorted as 36 on metal oxide, 19 on metal, and 12 on carbon in terms of types of NP. In particular, plants were most frequently used for the toxicity test including rice, wheat, bean, lettuce and pumpkin. E. feotida and E. veneta in earthworm toxicity test and $C$. elegans in soil nematode were favorites for many researchers above. The 41 studies can be also sorted to be 1 in 2005, the first year of Al nanoparticle research on plants, 3 in 2007, 12 in 2008, 16 in 2009 and 9 in 2010 so far. In terms of nationality, $46 \%$ of the researches were conducted in the US after which China (17\%), Korea (7\%), Denmark (5\%), Japan, Germany, Spain (each 5\%), UK, Belgium, Italy, Israel, India, France and Puerto Rico (each 2\%) were following (Fig. 1(B)). Researches on $\mathrm{C}_{60}, \mathrm{C}_{70}$, MWNTs, SWNTs and DWNTs in carbon based nanoparticles and $\mathrm{TiO}_{2}, \mathrm{ZnO}, \mathrm{Ag}, \mathrm{Al}_{2} \mathrm{O}_{3}$ and $\mathrm{Cu}$ in metal (oxide) based nanoparticles were performed.

As for dispersion methods within the test medium, sonication or mix were used in most cases except using solvent such as THF (Tong et al., 2007) and acetic acid (Ma et al., 2009). The researchers performed their studies on aquatic organism with usually carbon based nanoparticles, but more

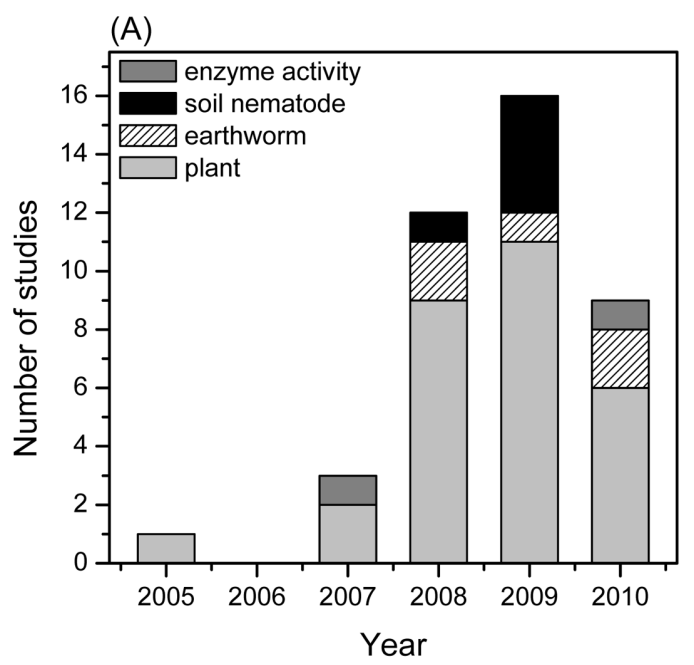

used metal (oxide) based nanoparticles for soil organisms. Carbon based nanoparticles were mostly used in early toxicity researches, but later, metal (oxide) based nanoparticles were vastly used. Soil toxicity studies, which came after aquatic toxicity researches, adopted much more metal (oxide) based nanoparticles as their materials. They were performed ion and micro toxicity test as controls against nanotoxicity. As for test medium, filter paper test, agar medium, and aqueous solutions for plants were used in the past, but currently various methods of mixing nanoparticles with soil or feed are being used.

\section{CONCLUSION}

To understand the current research trends of nanoparticle ecotoxicity in soil environment, research papers on nanotoxicity for soil biota including plant, earthworm, soil nematode were thoroughly analyzed and discussed in terms of the kinds of nanoparticles, test species, and exposure medium. We also included soil enzyme activity. The researches demonstrated the a wide range of results from one another even when using the same a nanoparticles because the particle size, surface coating, dispersion methods, and test medium supposedly made difference in the results. Therefore, future researches should be conducted by considering these factors. In particular, as soil media clearly affect their physico-

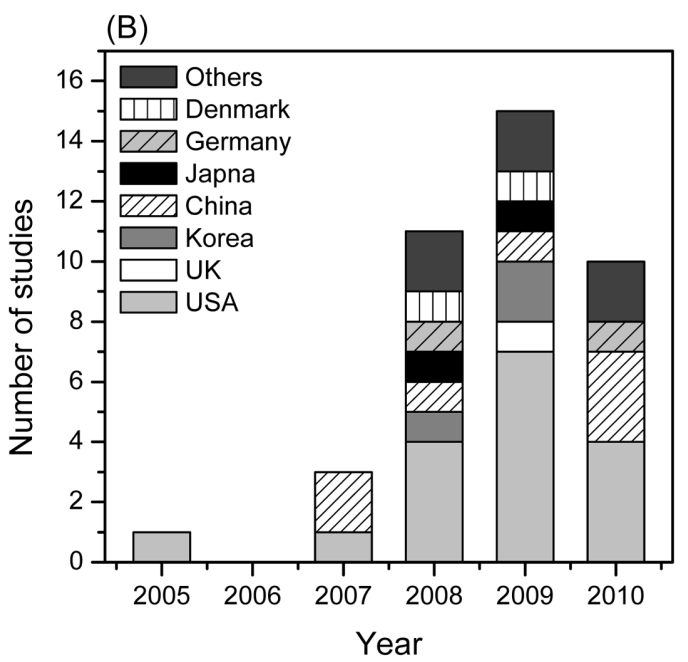

Fig. 1. Studies for nanotoxicity as related with (A) test species and (B) countries. 
chemical properties and fate of nanoparticles, future researches needs to be done in this regard.

\section{ACKNOWLEDGEMENTS}

This work was supported by the National Institute of Environmental Research funded by the Ministry of Environment as a part of OECD Sponsorship Program.

\section{REFERENCES}

Asli, S. and Neumann, P.M. (2009). Colloidal suspensions of clay or titanium dioxide nanoparticles can inhibit leaf growth and transpiration via physical effects on root water transport. Plant Cell Environ., 32, 577-584.

Barrena, R., Casals, E., Colón, J., Font, X., Sánchez, A. and Puntes, V. (2009). Evaluation of the ecotoxicity of model nanoparticles. Chemosphere, 75, 850-857.

Battke, F., Leopold, K., Maier, M., Schmidhalter, U. and Schuster, M. (2008). Palladium exposure of barley: uptake and effects. Plant Biology, 10, 272-276.

Cañas, J.E., Long, M., Nations, S., Vadan, R., Dai, L., Luo, M., Ambikapathi, R., Lee, E.H. and Olszyk, D. (2008). Effects of functionalized and nonfunctionalized single-walled carbon nanotubes on root elongation of select crop species. Environ. Toxicol. Chem., 27, 1922-1931.

Coleman, J.G., Johnson, D.R., Stanley, J.K., Bednar, A.J., Weiss, C.A., Boyd, R.E. and Steevens, J.A. (2010). Assessing the fate and effects of nano aluminum oxide in the terrestrial earthworm, Eisenia fetida. Environ. Toxicol. Chem., 29, 1575-1580.

Doshi, R., Braida, W., Christodoulatos, C., Wazne, M. and O'Connor, G. (2008). Nano-aluminum: Transport through sand columns and environmental effects on plants and soil communities. Environ. Res., 106, 296-303.

European Committee (2009). Regulation (EC) No. 1223/2009 of the European parliament and of the council of 30 November 2009 on cosmetic products.

Hänsch, M. and Emmerling, C. (2010). Effects of silver nanoparticles on the microbiota and enzyme activity in soil. J. Plant Nutr. Soil Sci., 173, 554-558.

Hoet, P., Bruske-Hohlfeld, I. and Salata, O. (2004). Nanoparticles known and unknown health risks. J. Nanobiotechnology, 2, 12.

Hu, C.W., Li, M., Cui, Y.B., Li, D.S., Chen, J. and Yang, L.Y. (2010). Toxicological effects of $\mathrm{TiO} 2$ and $\mathrm{ZnO}$ nanoparticles in soil on earthworm Eisenia fetida. Soil Biol. Biochem., 42, 586591.

Kim, J., Takahashi, M., Shimizu, T., Shirasawa, T., Kajita, M., Kanayama, A. and Miyamoto, Y. (2008). Effects of a potent antioxidant, platinum nanoparticle, on the lifespan of Caenorhabditis elegans. Mech. Ageing. Dev., 129, 322-331.

KORTRACT (2010). Analyst report; 나노물질 규제 동향 및 대 응 방안: 유럽연합, 미국, 대만, 우리나라의나노물질 규제 동 향, BSC Report 312-10-035.

Kumari, M., Mukherjee, A. and Chandrasekaran, N. (2009). Genotoxicity of silver nanoparticles in Allium cepa. Sci. Total Environ., 407, 5243-5246.

Lee, C.W., Mahendra, S., Zodrow, K., Li, D., Tsai, Y.-C., Braam, J. and Alvarez, P.J.J. (2010). Developmental phytotoxicity of metal oxide nanoparticles to Arabidopsis thaliana. Environ. Toxicol. Chem., 29, 669-675.

Lee, W.M., An, Y.J., Yoon, H. and Kweon, H.S. (2008). Toxicity and bioavailability of copper nanoparticles to the terrestrial plants mung bean (Phaseolus radiatus) and wheat (Triticum aestivum): plant agar test for water-insoluble nanoparticles. Environ. Toxicol. Chem., 27, 1915-1921.

Lin, D. and Xing, B. (2007). Phytotoxicity of nanoparticles: inhibition of seed germination and root growth. Environ Pollut, 150, 243-250.

Lin, D. and Xing, B. (2008). Root Uptake and Phytotoxicity of ZnO Nanoparticles. Environ. Sci. Technol., 42, 5580-5585.

Lin, S., Reppert, J., Hu, Q., Hudson, J.S., Reid, M.L., Ratnikova, T.A., Rao, A.M., Luo, H. and Ke, P.C. (2009). Uptake, translocation, and transmission of carbon nanomaterials in rice plants. Small, 5, 1128-1132.

Liu, Q., Chen, B., Wang, Q., Shi, X., Xiao, Z., Lin, J. and Fang, X. (2009). Carbon nanotubes as molecular transporters for walled plant cells. Nano Lett., 9, 1007-1010.

Loìpez-Moreno, M.L., de la Rosa, G., Hernaìndez-Viezcas, J.A., Castillo-Michel, H., Botez, C.E., Peralta-Videa, J.R. and Gardea-Torresdey, J.L. (2010). Evidence of the differential biotransformation and genotoxicity of $\mathrm{ZnO}$ and $\mathrm{CeO} 2$ nanoparticles on soybean (Glycine max) plants. Environ. Sci. Technol., In press.

Ma, H., Bertsch, P.M., Glenn, T.C., Kabengi, N.J. and Williams, P.L. (2009). Toxicity of manufactured zinc oxide nanoparticles in the nematode Caenorhabditis elegans. Environ. Toxicol. Chem., 28, 1324-1330.

Moore, M.N. (2006). Do nanoparticles present ecotoxicological risks for the health of the aquatic environment? Environ. Int., 32, 967-976.

Nel, A., Xia, T., Madler, L. and Li, N. (2006). Toxic potential of materials at the nanolevel. Science, 311, 622-627.

OECD (2009). Preliminary review of OECD test guidelines for their applicability to manufactured nanomaterials No. 15.

Petersen, E.J., Huang, Q. and Weber, J.W.J. (2008). Bioaccumulation of radio-labeled carbon nanotubes by Eisenia foetida. Environ. Sci. Technol., 42, 3090-3095.

Roh, J.-Y., Park, Y.-K., Park, K. and Choi, J. (2010). Ecotoxicological investigation of $\mathrm{CeO} 2$ and $\mathrm{TiO} 2$ nanoparticles on the soil nematode Caenorhabditis elegans using gene expression, growth, fertility, and survival as endpoints. Environ. Toxicol. Phar., 29, 167-172.

Roh, J.-Y., Sim, S.J., Yi, J., Park, K., Chung, K.H., Ryu, D.-Y. and Choi, J. (2009). Ecotoxicity of Silver Nanoparticles on the Soil Nematode Caenorhabditis elegans Using Functional Ecotoxicogenomics. Environ. Sci. Technol., 43, 3933-3940.

Scott-Fordsmanda, J.J., Krogha, P.H., Schaeferb, M. and Johansenc, A. (2008). The toxicity testing of double-walled nanotubes-contaminated food to Eisenia veneta earthworms. Ecotox. Environ. Safe., 71, 616-619.

Seeger, E.M., Baun, A., Kästner, M. and Trapp, S. (2009). Insignificant acute toxicity of $\mathrm{TiO} 2$ nanoparticles to willow trees. $J$. Soils Sediments, 9, 46-53.

Stampoulis, D., Sinha, S.K. and White, J.C. (2009). Assay-dependent phytotoxicity of nanoparticles to plants. Environ. Sci. Technol., 43, 9473-9479.

Tan, X.-M., Lin, C. and Fugetsu, B. (2009). Studies on toxicity of 
multi-walled carbon nanotubes on suspension rice cells. Carbon, 47, 3479-3487.

Tong, Z., Bischoff, M., Nies, L., Applegate, B. and Turco, R.F. (2007). Impact of fullerene (C60) on a soil microbial community. Environ. Sci. Technol., 41, 2985-2991.

UBA (2009). Nanotechnology for humans and the environment; Promote opportunites and reduce risks.

United Nations Environment Programme (2007). GEO Year Book 2007; An overview of our changing environment. Emerging challenges- Nanotechnology and the Environment.
Wang, H., Wick, R.L. and Xing, B. (2009). Toxicity of nanoparticulate and bulk $\mathrm{ZnO}, \mathrm{Al} 2 \mathrm{O} 3$ and $\mathrm{TiO} 2$ to the nematode Caenorhabditis elegans. Environ Pollut, 157, 1171-1177.

Yang, L. and Watts, D.J. (2005). Particle surface characteristics may play an important role in phytotoxicity of alumina nanoparticles. Toxicol. Lett., 158, 122-132.

Zhu, H., Han, J., Xiao, J.Q. and Jin, Y. (2008). Uptake, translocation, and accumulation of manufactured iron oxide nanoparticles by pumpkin plants. J. Environ. Monitor., 10, 713-717.

http://www.nanotechproject.org/inventories/consumer/analysis_draft/ 